in traning at the time of the passage of this Act, and shall graduate hereafter,

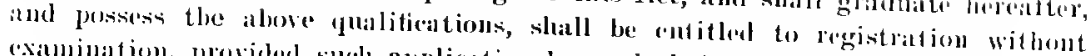
cxamination, provided sinch application be made before lnme l, lont.

Grablutes of tranumg-schools in connection with special hospitals, giving a two garse course, who shall obtain one years adthiomal traning in an approved gederal hospital, shall be cligible for registration withont examination

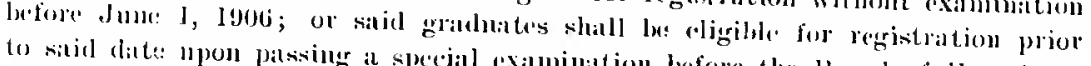

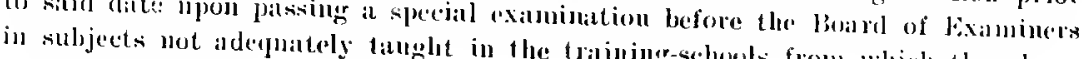
breng graduated.

And it shall be mulawful after the 10 practice professional mursiuer as a expiration of that time for any person this state. phovisions of thise who has received his or her certificate alcending to tho

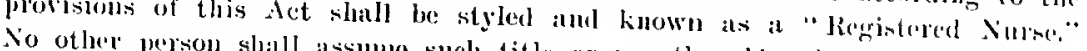

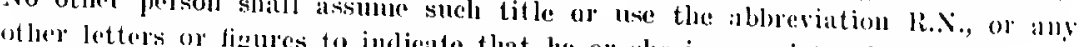

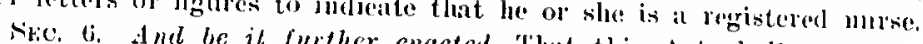

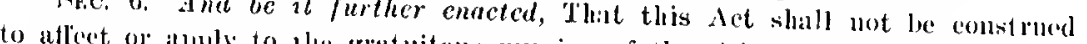

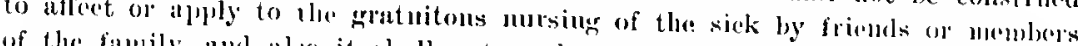
hire but who and also it slabll mot apply to any person mursing the sick for ske 7 dues not in any way assume to be a regintered nurse.

provisions of this it furlace enected, llat any person violating any of the

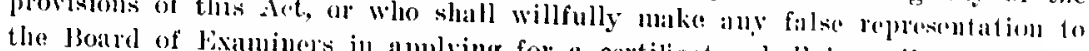

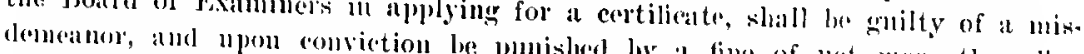
hundred dollars (\$500).00).

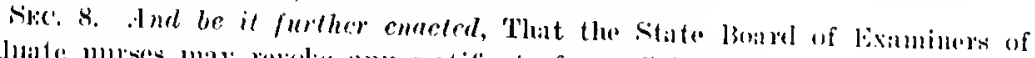

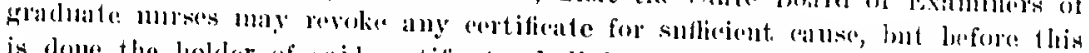

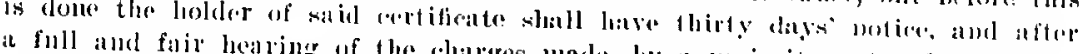
board, the eertilicate caln be revoked

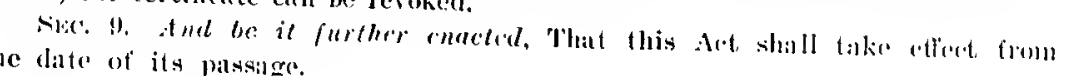
the date of its passigge.

\title{
THE INDIANA BILL FOR THE STATE REGISTRATION OF NURSES
} 1905:

'Tue Barron House Bill, No. 15, signed by Governor Hanley, Felmulay 27,

"A litu for an act requiring the regist ration of all trained nurses, porviding a Board of Registration and Hxamination, fixing the mmolere, flut ies, and qualifications of sitid bonrel, anel providing for the regist ration of unres, providing
penalties for violation of sabl act.

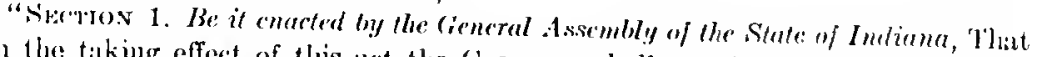
upon the taking effect of this act. the Governor slanll appoint, within sixty days, a State Board of Registration and lixamination of Nurses, to be compused of five exchusive of their trainimgad less than five-years' experience in their protessuon, of these members slatl be ales wo shall not be commected with any hospital. (me two for two years, and two for the by the arejuor to hold ollice for one year, 
the term of oflice of the person or persons so appointed the Governor shall appoint suceessors to such person or persons to lold office for three years. All vacancies oceurring on this bourd slall be filled by the Governor from persons qualified as above stated.

"Sice. 2. The members of the said State Hard of Registration and Examination shall meet in the City of Indianapolis as soom as organized, and annually thereafter in the montl of July shall elect from their members a president and also a secretary, who shall be the treasurer. 'llore members shall constitute a yuorum, and special mectings of the board shall be called by the secretary upon the written request of any two ntembers. 'The State Bonrol of laegistration and lexamination is autborized to frame such by-laws as may be necessary to govern its actions. 'The seceretary shatl be recpuired to keep a record of all meetings of the hoard, inchuring a reginter of the names of all nurses duly registered molor this act; salicl register shatl, at all reasomable times, be open to public serutiny, and the board shall ciuse the prosecution of all persons violating any of the provisions of this aret, and may ineur necessary expense on this behalf. The said by-liaws shall provide the subjects upon which applicants shall be examined. The sceretary shall receive a saliry to be fixed by the boturd not to exeed five lumbled $(\$ 500)$ dollars per annm, also travelling and other expenses incurred in the discharge of their oflicial duties. 'The otler members of the board shall receive five (\$5) dollars per chay for each day actually engagerl at the meetings of the board, and legit imate and necessary expense. Siat expense and saliay shatl be paid from fees received by the board under the provisions of this act, and no part of salaries or otler expenses of the board shall be paid out of the Sitate lreasury.

"swe. 3. The derk of the Circuit court of any rounty, upon presentation to him of a cortificate from the State Boarcl of Regist ration and lexamination, shall register the date of regist ration, with the name, residence, and address of the holder thereof, in a book to be kept in lis oflice for this purpose, and marked "liegister of Trained Nurses," and shall issue to the applicant a certificate of sueh registration muler the seal of the Circuit Court of the comty, for which registration he shatl be paicl fifty cents by the applieant.

"Sisc. 4. 'What after June 1, 1908, it shall be the duty of said Board of Registration and lixamination to meet not less frepuently than once a year. Notice of rach moeting shall be given in one daily newspaper and in one nursing or medical journal published within the state of Imblina thirty clays prior to saicl meeting. At these meetings it shatl be the duty of said hoard of Registration and Examination to examine the diplomas and credentials of all applicants for registration muler this act. Said boird shall also examine such applieants on the branches ustally taught in the training-schools for morses to determine their fitness and ability to give eflicient (are to the sick. The said loard shall require of each applicant for cxamination and registration a fee of ten (\$10) dollars, to be paid upon application.

"sice. 5. That after June 1, 1908, the applicant shall furnish satisfactory evidence that he or she is twenty-one years of age, of gocel moral character, has receivel the efuivalent of a lligh-sichool oducation, and has been graduated from a training-school for murses connected with a genemal hospital approved by the board, where a systematic eourse of two-years' instruction is given.

"SEc. 6. Any resiclent of the State of Indiana, being over the age of twentyone years, of good moral charaeter, holding a diplouna from a training-school for nurses connected with a general hospital giving a eourse of at least two-years' 
training or having had seven-years' experience, three of which shall have been spent in a general or special lospital and engaged in professional nursing at the date of ol prior to the passage of this act, shall be entitled to registration without examination, provided such applieation be made before January 1, 1906. All nurses in training at the time of the passage of this act and possessing the alove qualifications shall be entitled to registration without examination, provided application is made before. June 1, 1908. Ciraduates of training-schools in connection with special hosplitals giving a two-years' course who shall obtain six-montles' additional training in a general lospital approved by the state Hoard of Registration and Examination shall be eligilyle for regist ration without examinat ion lofore Jume 1, $190 \mathrm{~N}$; or said gracluates shall be eligible for registration prior to said date who have nussed five ycars prior to the passage of this aet; or upon passing of special examination before the Sitate Baard of Registration and Fxamination in sulbjects not ade juatcly tanght in the training-school from which they have lieen graduated.

"lhe by-liws shall provide for the exsumination and qualification of nurses who. make application before January 1, 1906, who have not graduated from a training-school, and who lave been rngaged in mursing ten years, and who are otherwigo eligible, and who shall present required credent ials from plyssicians for
whom they have nursed.

"All applicants uncler this section shall pay to the said board the sum of five (\$5.00) dollars at the time of making applicution.

"SEC. 7. The State lioard of Registration and kxamination shall have pewer, after thirty-days' notice, upon writien charge being preferred and the tince and place of meeting being fixed, and after full and free hearing of the same by a majority vote of theentire los ral, to revoke any license issued ly said hourd for gross incompetency, dishonesty, lichitual intemperance, or any other act in the judginent of the board derogatory to the morals or standing of the profession of nursing. shall be stricken from of the license or certificate the name of the holder thereof of the board and notice sent of same to the clerk of the liands of the secretary of

in which he or she resides, and there sliall be no appeal therefrom.

in aceordance with person who shall have duly received a license and certificate tered nurse,' and it shall be unlawfulis act slall be known and styled a 'regisfor any person to practise or anlawful after one year from the passage of this act cradinte nurse or to the title of trained nurse or let ters, or fig. 'I.'N.' or 'Ci. N.' or any otluer worls, or graduate nulve, indeate that the persolu using the same is a trained, registered, in accordanee with thes he or she shall love first meciverl a lieense and cortificate in aceordance witl the provisions of this act.

"SEc: 9. This act shall not be construed to affect or apply to the gratuitoms nursing of the sick by friends or members of the family, and, also, it shall not apply to any person mursing the sick for hire who does not in any way assmun to be a registereil or grachate nurse.

"St: 10. Nuy person violating any of the provisions of this act shall be guilty of a miselemeanor, punishable by a fine of not less than twenty-five (\$25) dollars and not more than fifty (\$50) dollars for the first offence, and not less than fifty (\$in) dollars and not more than one hundrerl (\$100) dollars for cach subsequent
offence." 


\section{THE COLORADO BILL}

I'He following is the Colorado bill as signed by Governor MaeJonald April 12 , 1905:

"A BILL for an act relating to professional nursing.

"Be it enacted by the General Assembly of the State of Colorado:

"Secrios 1. That within sixty days after the taking effect of this aet the Governor of the State shall appoint a State Board of Nurse Exaininers, to be composed of five members. Each of the inembers of said boarl so appointerl by the Governor shall be a trained nurse of at least twenty-three (23) yeass of age, of good moral eharacter, who is a graduate from a training-school eonnected with a general hospital or sanitarium of good standing where a three-years' training with a systematie eourse of instruetion is given in the wards; one of the members of said board shall be designated by the Governor to hold office for one year, one for two years, one for three years, one for four years, and one for five years, and thereafter upon the expiration of the term of office of the person so appointed the Governor shall appoint a sueessor to eaeh person to hold offiee for five years, each of whom shall be a registered nurse under the provisions of this aet and shall fulfil the requirements in this seetion set forth.

"SEc. 2. That the inembers of said board shall, as soon as organized, annually in the inonth of April elect from their members a presiclent and a seeretary, who shall also be the treasurer. Three members of this board shall constitute a quormun, and special meetings of saicl board shall be ealled by the seerctary upon the written request of any two members. The board is anthorized to make such bylaws and rules as shall be neeessary to govern its proceelings and to earry into effeet the purpose of this aet. The secretary shall be required to keep a record of all the meetings of said board, including a register of the names of all nurses duly registered under this aet, whieh shall at all reasonable times be open to publie scrutiny, and said board shall eause the prosecution of all persons violating any of the provisions of this aet, and may incur necessary expenses on that behalf. That the president and seeretary shall make a biennial report to the Governor on the seeond Monday of December immediately preeeding the convening of the Legi_lature, together with a statement of the rceeipts and dishursements of said board.

"SEc. 3. That after April, 1906, it slaall be the duty of said board to meet not less frequently than onee in every three (3) months, notice of which inceting shall be given to the publie press and in one nursing journal one month previous to the meeting. At said meetings it shall be the cluty of the hoard to examine all applieants for registration under this aet. Upon filing application for examination each applicant shall pay a registration fee of ten dollars. The examination shall be of such a charaeter as to determine the fitness of the applieant to practise professional nursing as contemplated by this act. If the result of the examination of any applieant shall be satisfactory to a majority of the board, the secretary sluall, upon an orcler of the board, issue to the applieant a certificate to that effeet; whereupon the person named in the certificate shall be declared duly qualified to pract ise professional nursing in this State. Any person from any other State who shall show to the satisfaction of the board that he or she is a trained, graduate nurse of a hospital or sanitarium, the standard of instruction and training of which shall meet the requirements of the rules preseribed by said board, may, upon payment of the usual fee therefor, reeeive a eertifieate and be registered as a nurse of this State without examination. 
“Sie. 4. That all nurses who are engaged in morsing at the dato of the passage of this act and who slasll slow to the sat isfaction of said board that they are gratnates of traning-selowhs conoceded with a hospital oi sandarinm giving two-years" gencril trining, or prion to the year 1301 lating given rightern-montles' general

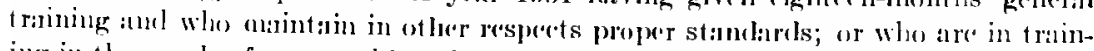
ing in the warels of a general hespital or sanitarium where a two-years' training with

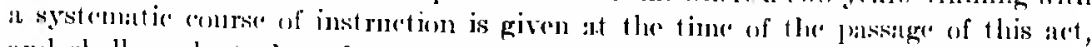

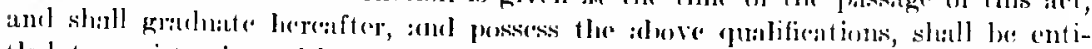
tled to regrist ration withont asmunation, provided som appliention be made to this board bofore April, 1906. It sloall be molawful after April, 1906, for any person

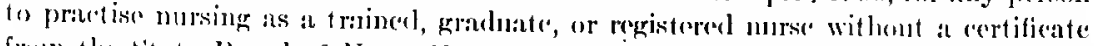
from the state Board of Nime lisaluniners. A nurse who has received his or her

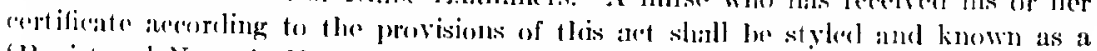

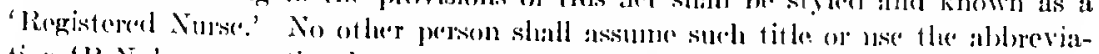
tien 'R.N.,' or any othere laters, to indieate that he or she is a trabed, graduate, or ropisterol numes.

"Ske. 5. That the state Board of Nurse lixaminess shall have the power to revoles any certificate issued in aceordanee with this act by umninous vote of saicl board for gross incomperteney, dishomesty, labitual intemperance, or any ace cleregatory to the morals or standing of tler profession of nursing, as may be dotermined loy

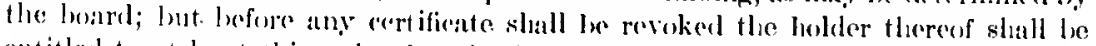
entitled to at least thirty-elayes notice in writing of the elarge agninst him or leer, and of the time and place of learing and determining of sucle charges, at whicle time and place le or she sluall be entitled to be leard. J jom the reveration of any certificate it shall be the dety of the serewtary of the hosard to strike the mame of the lobler thereof from the pell of registered nurses.s.

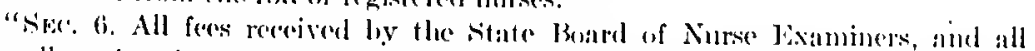

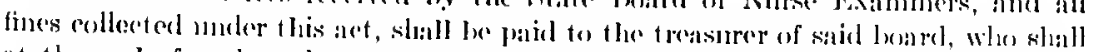

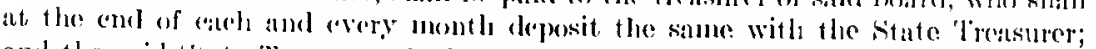
and the said state 'Preasurer slall place said money so roceived in a spectal fund to be known as the fund of the Sitate Board of Nurse Fiximiners, and shall pay the saune out on voudeders issued and signed by the president and secretary of said loard upon warrants drawn ly the Auditor of the State therefor. All moncyse so reecived and placed in said fund maty lee used by the State Buard of Nurse Lxaminers in def raying its expenses in earrying ont the provisions of this aret.

"Sise. 7. This act slabll uot. be construed to affeet or apply to the gratuiteus nursing of the sick by friends or normbers of the fanily ar to any person musing the siek for lie who does not in any way assume the practiere as a tramed, grachate, or registoresl murse.

"Swe. 8. That any person violating the provisions of this act, or who shall make any false representations to said board, in applying for al recrificate, shall be gnilty of a misdemeanor, and, mon couvietion, be punishod ly a finc of not more than there humdred dollars (s:300.(00); provided, that nothing in this act shall apply $t_{0}$ murses who have served as such in the army of the Cnited states in the Civil War or the spanish-dmerio:an War.

"SEc. 9. In the opinion of the (iencral Assembly an cuepgency esists; therefore, this arct shall take effect and be in force from and after its passige." 


\title{
STATE OF CONNECTICUT
}

\author{
AN ACT \\ reoulating the phactice of prolessional Numsing of THE sick \\ Becante at liw June 6 , 190j
}

SEction 1. From and after July 1, 1905, there shall be a board of exam. ination and registration of nurses, composed of tive members, appointed by the governor, and all vacancics in said board shall be filled by the governor in like nanner. 'The nember's of sild board shall be residents of the state of Connecticut and shall be practical nurses, each of whom shall be a graduate of a training-school for nurses whieh grives a two yeatrs' eourse in a general hospital, and shall lave had at least eight years' experience in professional nursing of the siek. Hatch nember sliall be appointed for a term of three years from the date when the appointment shall take ellect, except those first appointed, who shall serve as follows: one for one year, two for two years, and two for three ycars from the date theit appointments take cfleet respcetively, and except a person appointed to fill a vacincy, who shall be nppointed for the unexpired term.

Skc. 2. Said board shall, at the first meeting thereof, and at the annual meeting which shall be held on the first Wednestay in June, 1906, and on the first Wednesday in June in each year thereafter, clect. from its own number a president and a secretaly who shall also be treasurer. Said board may adopt a seal, and may adopt such by-laws, rules and regulations for the transaction of the business of the board and the government and management of its affairs, not inconsistent with the laws of this state and of the Linited states, as it may deem expedient. Three members of said board shall constitute a quorum, and special meetings shall be called upon request of any two members. On request of said board the comptroller slatl provide a snitable room in the enpitol for its neetings.

SEc. 3. The menbers of said board shall recive their actual nccessary expenses incurred in the discharge of their duties, and the seeretary shall receive a salary to be lixed by the board, not to exceul one lundred dollars per year. Said expenses and sidid silary shall be paid out of the receipts of said board as hereiniter specilied.

SEc. 4. It a meeting of said board to be lell within sixty days after the appointment of the members thereof, and at the anmual meeting in eneh year thereafter and at such special meetings as said board may deem neessary to hold for that purpose, notice of each of which meetings shatl be given by publieation in such newspapers as the board maty determine at leist one month previous to stuch neetings, said board shall examine all applieants for registration under the provisions of this act to determine their qualifications for the ellicient nursing of the sick. Any person twenty-one years of ane or over and of good moral character who shall show to the satisfation of the board that lie or she is a graduate of a training-school for nurses which gives a two years' course in a public or private hospital where medieal, surgieal, and obstetrieal rases are reecived and treated, or has had such experience as said board shall find to be equivalent thereto, shall be eligible for such examination upon payment of a fee of five dollars, to be deposited upon the filing of the applieation 
for examination. Said examination shall include the subjects of elementary and home sanitation. If sueh al, surgical, and obstetrical nursing, dietetics, satisfaction of the board, said applicant shall pass said examination to the sidid applicant.

SEC. 5. Any person twenty-one years of age or over character, applying for registration years of age or over and of good moral aet, and who shall, by affidavit or within two years from the passage of this board that he or she is a graduate of a two-years' course in a public or po a training-school for nurses which gives obstetrical cases are receivel or private hospital where nedical, surgical, and of this act, a student in such treated, or that he or she was, at the passage graduated therefrom, or has training-school for nurses and afterwards was to be equivalent thereto

upon payment of a fee of five dollars.

convieted of any felony, of ancel the registration of any person who has been profession of nursing.

Skc. $i$. It shall be unlawful, after two years from the passage of this act,
for any person to practice professional nursing in the nurse without having a ecrtificate of recristring in this state as a registered slleh certifieate shall be styled and registration. A nurse who has received otler person shall assume such titl known as a "Registeled Nurse," and no other words, letters, or figures to the, or nse the abbreviation "1R.N." or any such a registered nurse. Every to indicate that the person nsing the same is act, who sliall wilfully make false representation to sald brovision of this for a cortificate of registration, sepresentation to stid board in applying dollars; provifed, thit nothing in this actined not more than one hundred of any person nussing the sick who does not represent he apply to the acts a registered nurse. The bourd who does not represent himself or herself to be cuting oflicer avidence of any shatl cause to be presented to the proper proseineur nuy necessary expenses violation of the provisions of this aet and may to be paid out of the reccipts of said perforntance of this duty, said expenses

SEC. 8 all feeg collocted loril board

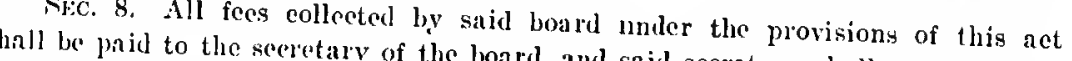
monces so received tlo saliry of said, and said secretary shall pay from the the members as provided in section thee of thy and the neessary expenses of and other necessary expenses of the of this act, also for books, stationery, create or incur no expense exceding the sum provided, that said board shall under the provisions of this act to the stite a bond, with surety, The secretary shall before taking office give the duties of side oflice, in the penal sum of and shill keep an aceount of all moneys reeived and than five hundred dollars; slibll render a detailed statement thereof to thed and expended as aforesaid and first in each year.

Swe. 9. This ard shall take effect from its passage. 